\title{
New Technologies Challenging the Practice of Journalism and The Impact of Education: Case of Northern Cyprus
}

\author{
Özen Çatal ${ }^{1 *}$ \\ ${ }^{1}$ European University of Lefke, Lefke, N. CYPRUS
}

Received 23 September 2017 - Revised 2 October 2017 - Accepted 16 October 2017

\begin{abstract}
The development of online journalism has generated a convergent media environment. This study is based on the assumption that the development of this new form of journalism plays a pivotal role in the transformation of the dynamics of professional practices, news production process as well as audience use and participation. It concentrates on investigating how and the extent to which this role is observed and can be explained in the context of Northern Cyprus. In this regard, it is argued that the prevalent journalism education curriculum offered in universities should be structured and diversified to include online journalism. Consequently, such will enable an increased focus on this environment in which multimedia opportunities, interactivity and hypertext possibilities can be found. On the other hand, while the concept of 'Citizen Journalism' has increased in parallel with the widespread use of new media opportunities such as social media; the findings in the present study suggest that the education on internet technology should be spread throughout the different social layers of society.
\end{abstract}

Keywords: online journalism, journalism education, interactivity, multimedia, hyper text / connectivity, North Cyprus

\section{INTRODUCTION}

Online journalism is defined as the implementation of professional journalist activities in an electronic environment that adheres to the general principles and rules of journalism (Bulunmaz, 2011). Furthermore, this involves presenting information in a different format to the audience through the utilisation of the inherent possibilities of conventional journalism technology, as can be understood from the definition. Internet journalism is now supported by faster, more visual and auditory elements, and is now an increasingly preferred medium, as it facilitates the audience's access to information and can instantly disseminate news without additional financial costs.

While the development of digital communication technology has introduced new functionality into our lives, such as multi-media, interactivity and connectivity, this advanced technology has also created new journalistic opportunities by developing new structures within the media industry. While Deuze (2003) defined Internet journalism as the fourth type of journalism, Pavlik (2001) claimed that communication technologies such as the Internet have established a new journalistic style, namely 'contextualized journalism'. According to Deuze (2004), the Internet has influenced the journalism profession in two aspects: the conception of a journalist profile for all media types and the creation of unique working practices.

The development of communication technologies has enabled the industry to exploit the increased possibilities of the Internet environment, meaning that the user can become an active participant in the communication process and can even produce their own content. This has led to a blurring of the boundaries between the journalist and the reader and there is also now no clear distinction between the different forms of media, such as radio, television and newspapers with boundaries are significant and different from each other.

The combination of changes in journalistic practices and the interactive participation of the audience have led to increased debate about the purpose of journalism education. The present study attempts to elucidate on the 


\section{Contribution of this paper to the literature}

- Contributes to the changing journalistic practices with new media technology.

- It sheds light on the effects of digitalization in journalism education.A programmable model is developed by applying graph theory for motion problems.

- $\quad$ Blend journalists' real life practices with academic debates

changes in journalism education by examining the different factors that have affected journalism practices through the development and spread of Internet journalism. As the new features generated by Internet technology have transformed the processes of news gathering, writing and distribution, thus the necessity to adapt journalism education to the changing requirements has increased. In this study, it is argued that there is a need to structure the existing education curriculum for university journalism departments and diversify in order to incorporate online journalism, where multimedia opportunities, interactivity and hypertext possibilities are prevalent. On the other hand, the development of Web 2.0 technology has blurred the boundaries between journalists and users; consequently, the definition of journalism is also transforming. The concept of 'Citizen Journalism' has attracted interest. Today, as Web 2.0 technologies continue to develop, the users have the capability to create their own content like journalists and can easily comment on existing news. Furthermore, in consideration with the aforementioned statements, this study also noted that the education on Internet technology should not be limited and should be spread throughout different social layers.

\section{New Skill Requirements Require a Transformation in Journalism Education}

One of the changes that online journalism has created in journalistic practices is the transformation of job descriptions, which are dependent on the change and diversified manner in which journalists now operate as a result of technological developments. Firstly, Internet technology, which offers multimedia facilities, has increased the demand for journalists who are capable of producing content that presents news incorporating elements such as images, sound, graphics and animation. As Stensen stated, "They had to master a great variety of technical skills, including some HTML editing and photo editing. They mastered all the different stages of production and publication themselves, from idea development to research, writing, editing, finding illustrations, publishing and post-publish editing." (Stensen, 2009), in addition to the ability to actually write about the news. Dilmen (2005) stated that journalists, who are now expected to have additional skills, such as video, sound and graphic design that enable them to produce news in a multi-media environment, are now defined by the new concept of 'Electronic Journalists'. Deuze (2004), in his study that evaluated the work of journalists and editors working in the new media environment, suggested that those journalists and editors believe that the new media environment improves their quality of work and their career opportunities; however, he also found that they spend significantly more time working on computers than on the street gathering news. Cetinkaya (2017), in his research on online journalism, employment and the transformation of job skills, emphasized that, despite the fact that the journalism profession remains essentially the same, the changes in terms of the platform and the fact that they are now predominantly technology-driven make it necessary for employees to acquire new skills. He also stated that this has created new roles within the industry, such as story builders, news flow managers, user-generated content editors (UGCs), digital rights managers, interactive content designers and social media coordinators.

All these factors indicate that a new approach is required for journalism education, since "The Web and its related technologies have significantly influenced not only the ways in which news is consumed, but also how journalism education and the on-going training of news professionals are undertaken" as Okoroafor stated (2016). Jordan Press (2015), suggested that journalism schools should not only educate their students to be journalists, but also guide the next generation of news consumers in navigating the modern news ecosystem. A study conducted on communication faculties in Turkey revealed that there is a wide variety of different courses with different approaches for teaching new media journalism and that education has not yet reached a homogeneous level in this regard (Akgül \& Akdağ, 2017). Du and Lo (2014), who conducted research on Asian journalism students, identified that traditional journalistic skills are still prioritized over technical skills; however, journalism curricula should educate students on both journalistic skills and computer skills.

\section{Media Sector in North Cyprus and Internet Journalism}

Eighteen daily newspapers are currently active in North Cyprus. Some of these newspapers are essentially operated as media organ for a political party by using news gathered from different agents, without producing any unique news, with the intention of bringing their affiliated political parties' activities to the forefront. Some of the daily newspapers that publish material with limited staff produce special news articles, although the rest of the contents are comprised of news from other agencies. The top four or five newspapers in terms of circulation, on the 
other hand, still operate in an institutionalised structure, and it is observed that these newspapers also have their own television and radio channels. According to the data of the Supreme Council of Publications, in addition to the daily newspapers, there are 14 television channels, three of which are state operated, seven private television stations, four university television channels 38 radio stations, 27 of which are private, 5 are operated by the state and 6 are university radio stations http://www.kktcyyk.org/?q=node/26 (Access: 08.07.2016).

As to be revealed in this study, Internet journalism has now been active and widespread for several years in North Cyprus regardless the short-term experiments that were not successful in the past. Internet journalism became popular on a global basis in the 1990s, although its impact was experienced in North Cyprus in the 2000s. Therefore, although the public in North Cyprus was relatively slow to appreciate online Journalism in comparison to the rest of the world, it is now increasing its influence on society.

The Internet was first introduced in the country in the 1980s although its progress was very slow. Furthermore, it began to be used in the field of journalism towards the end of the 1990s. Further analysis reveals that the lifespan of the first Internet newspaper in Northern Cyprus was relatively short, and it was terminated soon after its establishment. This online newspaper was created by an organization called "The Cyprus Communication Centre" and was established under the name "Kimgazet" by the journalists Süleyman Ergüçlü and Ferhat Atik. In a post on the Kibris Postası Internet newspaper, one of the aforementioned founders of the first Internet newspaper, Süleyman Ergüçlü (2011), expressed that in 1997, the time when Kimgazet was first published, there was not adequate Internet access in the T.R.N.C and he also added that the only organisation with adequate Internet infrastructure was Eastern Mediterranean University, which made it the only effective channel. Ergüçlü noted that, because of these drawbacks, the target audience could not be reached, and therefore this initiative did not receive sufficient advertising support and was terminated for economic reasons.

The online dissemination of newspapers began with publications on the Internet environment, in addition to the printed publications of newspapers in the T.R.N.C. Kibris Newspaper, a publication with wide circulation in the country, became the first newspaper in the TRNC to be published on the online environment. Other daily newspapers soon followed the Kibris Newspaper, which first published an online version of its newspaper in 1997.

In terms of the process, after the introduction of online newspapers, the daily print newspapers began to transition some of their content to the Internet environment after the distribution of their newspapers. It was observed that only the Internet newspapers publishing news on the Internet were able to actively report on developing stories that occurred during the day, which motivated the daily newspapers to follow suit and provide updates on last minute news and the latest developments.

Moreover, the analysis of the Internet newspapers published in the T.R.N.C, reveals that the Internet sites generally include the first pages of the daily newspapers in the "PDF" format in the morning as well-the daily columns prepared by regular columnists and important news items; furthermore, some news items from the online newspapers are published concurrently with the printed newspapers. Considering this fact, it is possible to say that the printed daily newspapers and the Internet newspapers feed and support each other.

As mentioned previously, despite the initial attempts to launch the Kimgazet online newspaper were unsuccessful as it closed after a short period of publication, Internet journalism in North Cyprus is now more established and has an improved media structure. In fact, it can be now considered that the Kibris Postasi newspaper, with its own news centre, special news reports as well as its professional correspondents and columnist staff, is the pioneer in this field in North Cyprus. By taking into consideration that the Kibris Postasi came into operation in 2002, it was observed that some of the more established print newspapers began to develop their own online news channels after that time. Kibris Postası, which is owned by Polat Alper on behalf of Citypress Publishing Ltd., became active in 2002 and subsequently encouraged many other newspapers to start publishing online, particularly as the popularity was observed to increase in the following years. The unique feature of Kibris Postası in the history of T.R.N.C. journalism is that it initially launched purely in the Internet environment, which was unprecedented in the county, and subsequently began to be published in printed form. Although Kibris Postasi became the first online newspaper in the TRNC in 2002, it is interesting that it began to publish a printed version of the newspaper with the same name on November 15, 2013.

Following the establishment of Kibris Postasi in North Cyprus, the number of Internet newspapers has increased in the country leading to the current situation where there are 30 online newspapers in the country served by 15 Internet service providers, according to data provided by the Media Ethics Committee. However, as Hüseyin Güven (Former Chairman of the Media Ethics Committee) (2014) stated, among those, the number of institutions operating with professional and qualified journalists numbers only three or four ( $\mathrm{H}$. Güven, personal communication, February 20, 2014). 


\section{METHODOLOGY}

This study, based on the assumption that the development of online journalism has a certain impact on the changing dynamics of professional practice and the news production process, concentrates on the question of to what extent and how this role can be seen and explained in the context of Northern Cyprus. The initial findings presented here are based on descriptive research, where qualitative methods were used in the collection of data. This included in-depth interviews with the journalists working in three online newspapers along with the observations of the respective workplace and websites. The group of participants was formed by six professional journalists, who work for those online newspapers as a full time staff.

This study aims to reveal how Internet journalism changes the journalistic professional practices and news production processes with a particular focus on journalism in North Cyprus in addition to reveal the current state of Internet journalism through in-depth interviews with media professionals working in this sector in North Cyprus. This method was used to collect first-hand detailed date and the interviews were conducted in the working environments of the cited professionals. Thus, observation of the working environments was also important in terms of supporting the data obtained in the conducted interviews. The collection of data, which formed the basis of the analysis, was conducted from May 2015 to the end of 2016. Some of the analyses used in the following sections, were completed in February 2017 and other stages of the research were carried out. The Internet newspapers included in the scope of the research were Kıbris Postas1, Gazete 360 and K1bris Net Haber. The names of the journalists were kept anonymous and they will be referred as Journalist 1, Journalist 2, Journalist 3, Journalist 4 , Journalist 5 , and Journalist 6 throughout the study. The interviews were conducted with the owners, web editors and journalists of the above-mentioned online newspapers.

\section{Data Collection and Analysis Procedures}

This study incorporates some of the findings of a PhD dissertation in progress and is based on a compilation of selected sections from detailed interviews conducted with media professionals working in Internet journalism. The statements made by the media professionals during the interviews were included in the article without any alterations. The observations of the working environments of journalists' during the interviews are additional data for this study. In the selection of the Internet newspapers for this article, the criteria indicated that they should have an institutional structure that enables the production of unique news extended beyond the practice of agency journalism and the newspapers should also employ professional journalists. The data was collected through structured interviews with a set of open-ended questions and each interview took between $30-45$ minutes. The questions were designed as to reveal the experience of the journalists in the field of online newspaper practices and to compare and contrast the conventional newspapers and to display the differences between online newspapers and the conventional newspapers. During the interviews, the researcher put a consideration to explicitly elaborate on the issues by asking further related questions when needed.

\section{RESEARCH FINDINGS AND DISCUSSIONS}

\section{Opinions and Comments of the Professionals Concerning the Features of the Internet}

Although the definition of online journalism differentiates it from the conventional forms of journalism, it is still based on the core principles of the profession. However, a differentiation has been generated in terms of the formal and practical practices of conventional journalism due to the possibilities provided by the Internet infrastructure. The possibilities created by the Internet environment include the ability to collect and distribute news faster by removing the boundaries of time and space as well as accommodating different media tools, blurring the boundaries between news sources and readers (users) and making different documents easily accessible within the news presentation; moreover, these are the main features that distinguish online journalism from conventional journalism. In this study, data obtained through interviews and observations are subjected to the analysis by classifying them in terms of their characteristics. In other words, the features are categorised under the titles of promptness, interactivity, multiplicity and hypertext in the evaluation of online journalism in terms of professional practice.

\section{Promptness}

One of the factors that differentiates Internet news reporting and enables it to surpass traditional reporting types is the promptness of the internet. Promptness is an emerging feature on the Internet, which means that accessibility is not determined by spatial limits, and there are no limitations imposed by frequency or time. For instance, Kibris Postasi's slogan "Never leave today's news until tomorrow" emphasizes this promptness factor in online journalism. In conventional newspapers, events that occur during the day are found on newspaper pages 
Table 1. Promptness

\begin{tabular}{lc}
\hline Outline of Answers & Theme \\
\hline 1. Online journalism requires significantly more prompt compared to conventional journalism & Promptness \\
\hline $\begin{array}{l}\text { 2. There are more control mechanisms in conventional newspaper, while this process is much shorter in online } \\
\text { journalism. This enables news to be prepared and published in a shorter time. }\end{array}$ & Promptness \\
\hline 3. The promptness factor increases competition among online newspapers. & Promptness \\
\hline 4. Promptness is necessary in online journalism, however it leads to mistakes. & Promptness \\
\hline 5. Confirmation of the news and verification should be consistently applied. & Promptness \\
\hline
\end{tabular}

Table 2. Interactivity

\begin{tabular}{ll}
\hline Outline of Answers & Theme \\
\hline $\begin{array}{l}\text { 1. Internet newspapers have many possibilities for interactivity, such as email, message forms, phone, social media } \\
\text { messages, and commentary sections that allow comments to be posted. }\end{array}$ & Interactivity \\
\hline $\begin{array}{l}\text { 2. When comparing feedback received via the Internet with the conventional media it is evident that the process is } \\
\text { significantly faster. }\end{array}$ & Interactivity \\
\hline 3. Audiences are more likely to send messages via social media. & Interactivity \\
\hline 4. Provided it does not contain profanity, a policy will be followed to publish all feedback. & Interactivity \\
\hline $\begin{array}{l}\text { 5. All comments from readers do not receive responses from editors, but personal } \\
\text { messages do. }\end{array}$ & Interactivity \\
\hline 6. The comments on the news content are not considered as a factor in the transformation of the news. & Interactivity \\
\hline
\end{tabular}

the following day. Radio and television broadcasting, on the other hand, provides a faster stream of news than newspapers, but there are limitations such as broadcast flow, news timing and duration. Examination of Internet news reporting reveals that it is possible to enable the audience to access news immediately.

Internet newspapers are another form of media, which is significantly faster and more engaging. As conventional newspapers operate with a system whereby the newspapers are printed the following day, there is less pressure caused by the race against time. However, on the Internet, it is necessary to meet the audience's demand for promptness, by informing them immediately of new developments. There are hierarchical relationships in conventional newspapers with many control mechanisms; on the other hand, in online newspapers and control mechanisms are more limited. This also enables prompt publishing of the news. As online journalism is based on the promptness of competition in the modern environment, it is evident that more errors are made in reporting in comparison to the written media. In some circumstances, in order to report news faster than the competition, incorrect or unverified news is also published. According to the results of the research, Internet journalists emphasize the importance of the promptness required by Internet journalism but also believe that it also increases the likelihood of committing errors.

\section{Interactivity}

In comparison to conventional forms of media, in which the process of providing feedback is both limited and complex, the interactivity features of new media mean that the process of giving feedback on online journalism is straightforward and it also facilitates the active participation of users in the content creation process. In comparison to the slow feedback process in the conventional media, in the Internet environment, feedback can be gathered through email, chat rooms, and online continuous surveys or forums without the need for any other means of communication (Mannteufel, 2002; Aktaş from 2007). Consequently, this leads to increased feedback on the Internet and more active participation in the process of content creation. At this point, it is important to state that interaction differs from feedback. According to Öğüt (2005: 5), "The recipient has the option to intervene without receiving the entire message that the source has designed. Thus, the source also tends to change the main transmission in line with the interaction", which means that the process of reshaping the transmission is emphasized as opposed to the feedback.

The research revealed that feedback from Internet users is more immediate and intense than in the conventional media; furthermore, it is observed that there are no separate positions that are responsible for evaluating the comments, e-mail, and message content received from the audience. It was also revealed during the interviews that the comments on the news content were not considered as a factor in the transformation of the news. This interaction with journalists and readers in the online environment, as understood by its definition, only occurs provided that it actually contributes to the transformation of the existing content. It is possible to say that in the case of the Internet newspapers published in North Cyprus, the news content is not shaped in line with the comments of readers; furthermore, these newspapers do not effectively exploit the benefits that online feedback can generate and their use of interactivity features does not differentiate them from the conventional media sources. In a different perspective, it was identified that social media has a significantly important role for Internet 
Table 3. Multimedia

1. There is a technological infrastructure in North Cyprus which prevents the effective use of multimedia facilities.

2. Internet newspapers have limited opportunities for producing videos by themselves due limited financial resources and lack of personnel.

Table 4. Hypertext/Connectivity

\begin{tabular}{lc}
\hline Outline of Answers & Theme \\
\hline $\begin{array}{l}\text { 1. The access to texts containing earlier versions of news and background information is more commonly presented } \\
\text { as an option to the audience through hyperlinks. }\end{array}$ & Hypertext \\
\hline 2. Internet newspapers largely use internal hyperlinks to allow readers to navigate within the site. & Hypertext \\
\hline 3. Hyperlinks are widely used on Internet newspapers to provide access to advertisers' sites. & Hypertext \\
\hline
\end{tabular}

newspapers, as more readers access news content from social media channels such as Facebook and Twitter than from the newspaper website directly.

\section{Multimedia}

Telecommunications, one of the most important features of the new media, leads to a convergence of new media through the use of multimedia, which brings data communication and audience communication together in a single vehicle (Van Dijk, 2004; Değirmencioğlu from 2011). News that is presented with images in printed publications can also be supported on the Internet with video and audio sources. This multimedia feature of the Internet has emerged as a result of technological convergence. "The convergence is defined as the ability to combine different communication platforms to present fundamentally similar service types" (Yildırım, 2010). Voice, text, video, graphics, etc., can be incorporated on the same platform, thus removing the boundaries between the related sectors. Yildirim (2010), by referring to the ILEF report published in 2007, noted that the sectoral and technological dimensions form the convergence that exists between digital communication technologies and conventional media. In terms of the media sector in North Cyprus, it can be said that in terms of the newspapers, radio, television and Internet sites, it is possible to observe evidence of technological convergence, while in the majority of the newspapers that only operate in the online environment, the multimedia usage is relatively limited.

The results of the study reveals that the ineffective usage of multimedia features in North Cyprus on Internet news websites is largely caused by the lack of appropriate technological infrastructure. Furthermore, this study found that advertising revenues are extremely limited, which means that it is not possible to employ sufficient personnel for news production activities using multimedia features.

\section{Hypertext/ Connectivity}

One of the benefits provided by Internet technology to online journalism that is not available through conventional media, such as newspapers, radio and television, is connectivity through hyperlinks. This mechanism of "hyperlinks making documents related to each other" (Kırçıl et al., 2003: 4) enables the possibility of switching to another text, image, etc. by clicking on a highlighted word or group of words. These transitions could be made to another source of news, image or sound within the site itself, or it could be in the form of a transition to various texts or materials on different Internet sources.

It can be observed that on Internet news sites, the access to texts containing earlier versions of news and background information is more commonly presented as an option to the audience through hyperlinks. It is therefore apparent that many Internet sites resort to external sources, as they do not have the capability to transmit video news. Another finding that emerged as a result of the interviews is that one of the common applications of hyperlinks is to link with the advertisers' pages. This shows that online newspapers consider hyperlinks as tools that can be effective at increasing advertising revenue.

\section{Features of the Internet News Centres and Annunciation Practices}

This study examines the changes and transformations brought to journalistic practices by online journalism as well as the dimensions of these changes. Furthermore, the structure of the news centres and organisational forms of news sites are questioned and the study attempts to reveal whether they exhibit differences to conventional journalism practices. When the structures of conventional news centres are examined, it is observed that openoffice structures are predominantly used, where reporters, editors and news directors can easily communicate with each other. One observation from this study is that the Kibris Postas1 newspaper has similarities with the 
Table 5. News Practices

\begin{tabular}{ll}
\hline & Outline of Answers \\
\hline Conventional Newspapers & Online Newspapers \\
\hline 1. News gathering on the street & Desk-side reporting \\
\hline 2. Regular news meetings applications & Communication via social media \\
\hline 3. Clear distribution of tasks and a large number of employees & Multi skilled, fewer staff \\
\hline 4. Requires journalism skills & Requires journalism skills \\
\hline 5. Common use of 5W1H and inverted pyramid & Common use of 5W1H and inverted pyramid \\
\hline 6. Detailed, longer news and subtitles & Shorter, spot news and interesting headlines \\
\hline 7. Use special news every day & Rare use of special news \\
\hline 8. News follow-up and & $\begin{array}{l}\text { News agencies, foreign websites, radio, TV social media are } \\
\text { commonly used as news sources }\end{array}$ \\
\hline 9. News updates are not possible & Continuous news update \\
\hline
\end{tabular}

conventional newspaper structure. At the offices of Kibris Postas1, which was first published online in 2001 and subsequently began to release a printed newspaper in 2015, there is a large round worktable where the reporters can collaborate and communicate easily. Although it is noticeable that the news director has a separate desk, it is not located in a different environment and is in fact adjacent to the rest of the reporters. The reporters working in the printed news section also have a collaborative working environment where news can be exchanged, which is located in another room. Although the reporters producing news for the newspapers are also operating in a convergent structure in which they produce news for the Internet environment, the physical working areas of the reporters of the printed newspaper and the online newspaper are different.

In-depth interviews with Internet journalists have helped to obtain general information about their working practices. Based on these findings, it is evident that Internet journalism has become an independent field of work, and journalistic activities can be conducted in any location through the use of mobile phones or laptops. However, Internet journalists are not constantly producing news on the streets in the same manner as conventional newspapers. One of the reasons for this is that the number of employees working for online newspapers is more limited. Unlike conventional newspapers, there is no separate reporters produce news regularly. Conventional newspapers have reporters whose job is to search for news on the streets and different employees conduct other tasks. As can be observed, the Internet news sites in the T.R.N.C. generally have limited budgets and fewer employees. One of the changes revealed in the practices of online journalism is that the employees do not conduct news activities during the day in the same environment and the communication between the employees is performed by means of the Internet, because journalistic activities are now conducted throughout the day. In this process, communication between the employees is achieved through the virtual environment.

As Gürcan emphasized (2002), “The definition and function of news reveals the same features throughout the mass media; the news is independent of the feature of mass media. Formatting in different ways and communicating through different mediums does not change the standards that news should have". Although the concept of news is the same in all forms of mass media, changes have been observed in terms of the manner in which the news are presented on the Internet, based on the browsing behaviours and expectations of users. There are different applications from traditional journalism in the techniques of news gathering, editing and writing. Dube stated that online journalism is a combination of both written and visual media, and publishers prefer a simple writing style, which makes it easier to follow the news online (Detrani, 2011). These assertions have also been confirmed in the interviews with employees of the Internet newspaper in Northern Cyprus. The journalists noted that the main forms of journalism used in news writing still retain their significance. As in conventional journalism, the $5 \mathrm{~W} 1 \mathrm{H}$ rule and the inverted pyramid technique are still important in Internet journalism, and are used in news writing. However, changes can be observed in that more concise stories are now produced with shorter, more interesting titles in Internet journalism, which is a result of the promptness of this form of media.

\section{CONCLUSION}

The academic studies on the transformation that online journalism has created in journalism practice has focused on these changes from four perspectives; workflow, changes in news gathering practices, the impact of acceleration on news content production patterns, and convergence in print, broadcast and online applications (Mitchelstein et al., 2009). Deuze emphasized the concepts of connectivity, multimedia, and interaction that constitute the important character of online journalism as 'ideal- typical'. In an online environment, the journalist decides on the media format or how the format can convey a story in the most effective manner (multimedia), the interactivity the audience uses to communicate with the journalist (interactivity), and what other stories, resources, the story will be linked to via hypertext. This is the 'ideal-typical' form of online journalism (Deuze 2001 \& 2003; Aktaş 2007). While abiding by the general principles of journalism, it is clear that features such as hyper-text / 
connectivity, multimedia, interactivity, are all important characteristics of online journalism, and they have engineered important changes in professional practice.

As Rafaeli (1988) stated "Interactivity is an expression of the extent that in a given series of communication exchanges, any third (or latter) transmission (or message) is related to the degree to which previous exchanges referred to even earlier transmissions". These both allow online journalism to emerge as a distinctive feature in that communication between the source and the user is immediate and can affect the message. The definition provided by Carrie Heeter about interaction that has been used by many communication scientists has been helpful in measuring the specific features of the media that allow interactive communication (Heeter, 1989 from Aktaş 2009). According to Aktaş, the available interactivity consists of six sub-dimensions, namely the complexity of the available options, the effort of the user in reaching the information, responding to the user, monitoring the usage of information, ease of adding information as a source of knowledge for the user and facilitation of interpersonal communication. Concerning the interviews conducted with the employees of the Internet newspapers, it seems that the interaction features are technologically available, but the interaction is not fully effective in terms of the usage, as emphasized by Heeter (Heeter, 1989 from Aktaş 2009). It appears that there are available commentary sections under news texts where users can provide feedback via email or communication forms in the Internet newspaper, as well as mass feedback from users by means of Facebook and Twitter sharing, although it is evident that this has no effect on changing the content of the news. Not only posts shared by the public on social media but also the sharing of politicians, social issues as well as the sharing in respect to new developments are all evaluated as subjects worthy of news reporting and so, instead of being shared directly with the users, they are translated into news format.

Quick access user habits have been introduced to people's lives through modern Internet technologies and the effects of the Internet technologies can be interpreted as having a significant impact on the manner in which news is created through online journalism. Fast consumption habits are reflected in the access to information, as the aim of users is to acquire information about the day by accessing Internet newspapers via tablets or phones quickly and in doing so, instead of reading the news in detail, which creates an environment where the news is quickly scanned; this is reflected in the news writing style that has been adapted to this form of news consumption in the online journalism of North Cyprus. The needs of users such as instant access to news and brief information reflected in the writing techniques in the form of short, simple spot news. Moreover, as Internet newspapers become more widespread, the increased competition, either with each other or with media applications, has weakened the method of confirming news from different sources in conventional journalism and has caused the spread of a form journalism that, in an attempt to include more information in the shortest possible time, leads to more errors or incomplete information.

Internet news has the distinctive feature in terms of the ability to combine the features of conventional media, such as radio, newspaper, and television, each of which has its own unique news format due to its different technical infrastructure. However, one of the findings of this study showed that this multimedia feature has not been used effectively in the newspapers of North Cyprus. Multimedia opportunities are defined in two ways (Deuze, 2004 and it involves two or more different media formats such as audio, text, music, still or moving pictures or submitting news packages through different media, including hyper-text, web site, newsgroup, e-mail, SMS, MMS, etc.; It appears that, the usage is limited due to the lack of infrastructure in North Cyprus,. This limitation is because of the lack of financial resources, as well as the personnel and technological inadequacies of the Internet newspapers. The Internet newspapers do not have sufficient personnel to produce news in different formats and these low staffing levels are largely caused by insufficient advertising revenue. For similar reasons, the technological infrastructure cannot be developed, which means that news presentation is mainly implemented by using photographs and texts.

The feature where texts are connected internally or externally with links (Deuze, 2003), is applied as by the news sites covered by the research, as well as giving links to other news within the same site. Additionally, this feature that is known as hyper texting, appears to result in news text becoming shorter. The habit of giving background information in traditional news writing formats has been abandoned in online journalism and is applied as a link to news that has been prepared in advance. On the other hand, it seems that referring users to the Internet newspaper through links that are shared on social media such as Facebook and Twitter is a frequently applied practice in the Internet newspapers of North Cyprus.

Along with online journalism, it is understood that the boundaries imposed by working hours for the sector employees in North Cyprus and the working space limitation have been eliminated. Some of the journalists said that online journalism is being performed as a secondary job both outside the working hours and during working hours, during the day. The newspapers, which are predominantly focused on the way in which the news meetings are implemented on the Internet environment, reveal that the publication of special news reports is restricted and only several are published every week. It is seen that $5 \mathrm{~W} 1 \mathrm{H}$ and the inverted pyramid techniques are both common, 
although the short news' reports are prepared for Internet users to meet their demands for rapid news consumption, as they are in other journalistic circles.

In other words, it is revealed that in terms of online journalism in North Cyprus, the possibilities offered by Internet technology, in which conventional journalistic habits are still maintained to a great extent, are limited by the factors listed above. The findings suggest that the Internet cannot be considered independently from the other social, economic and cultural dynamics that it interacts with; furthermore, the role of technology in practice can be understood together with these dynamics and the past habits of production and usage; and this supports the general theoretical stance that online journalism cannot be regarded as a transformative actor on its own.

When journalism education is evaluated in consideration of all these data, it is important to create a new curriculum by combining traditional journalism and education for new media. Despite the fact that new media technologies are continually being developed, journalism preserves its core essence, and accordingly the basic issues such as $5 \mathrm{~W} 1 \mathrm{H}$-based journalism education and journalistic ethics remain important. Although it has not lost sight of its origins, the transformation experienced in journalism practices due to applications such as multimedia, interactivity, and hypertext has required the acquisition of new skills for both the journalist and the user. From these two factors, it can be concluded that the inclusion of new media literacy and technology skills to curricula is one of the requirements of the modern era in additional of traditional journalism courses in journalism education.

\section{REFERENCES}

Akgül, M., \& Akdağ, M. (2017). Türkiye' de yeni medya eğitimi üzerine niceliksel bir betimleme. Academia, 5(1), 210220.

Aktaş, C. (2007). İnternet'in gazeteciliğe getirdiği yenilikler. Selçuk İletişim, 5(1), 31- 41.

Aktaş, C. (2009). “Çevrimiçi ortamda yayınlanan Türk gazetelerinin etkileşimin farklı boyutlarında bulunan özelliklerini kullanma düzeyleri üzerine ampirik bir çalışma. Marmara İletişim Dergisi, 14, 7 - 20.

Alper, P. (2013). Kibris Postasi 12th Year Vision. Retrieved on 24 May 2014 from http://www.kibrispostasi.com/index.php/cat/1/col/169/art/19938/PageName/KIBRIS_POSTASI

Broadcasting Supreme Council. (2016). "Kuruluşlar" Broadcasting Councils. Retrieved on 08 July 2016 from http:/ / www.kktcyyk.org/?q=node/26

Bulunmaz, B. (2011). İnternet gazeteciliğinin medya dünyası içindeki rolü ve ekonomik boyutları. Marmara Communication Journal, 18, 27-46.

Çetinkaya, A. (2017). Basın işletmelerinde çevrimiçi gazetecilik ile istihdam ve işgücü becerilerinin dönüşümü, Akademia, 5(1), 380-398.

Değirmencioğlu, G. (2011). Yerel basında yeni medya ve sosyal paylaşım sitelerinin kullanımı: Kocaeli'de yayımlanan yerel gazetelerin internet siteleri üzerine bir inceleme. Online Academic Journal of Information Technology, 2(5), 20-31. doi:10.5824/1309-1581.2011.4.002.x

Detrani, J. R. (2011). Journalism: Theory and Practice. Canada: Apple Academic Press.

Deuze, M. (2001). Online journalism: modelling the first generation of news media on the World Wide Web. First Monday, 6(10). http://journals.uic.edu/ojs/index.php/fm/article/view/893/802.

Deuze, M. (2003). The web and its journalisms: considering the consequences of different types of newsmedia online. New media and society, 5(2), 203 - 230. doi:10.1177/1461444803005002004

Deuze, M. (2004). What is multimedia journalism? Journalism Studies, 5(2), 139-152. doi:10.1080/1461670042000211131

Dilmen, N. E. (2005). Yönetenler açısından Türkiye'deki internet gazeteleri ve haber portalları üzerine bir değerlendirme. İstanbul Üniversitesi İletişim Fakültesi Dergisi, 22, 91-101

Do, Y. R. \& Lo, S. C. E. (2014). The gap between online journalism education and practice: a Hong Kong study. Journalism \& Mass Communication Educator, 69(4), 415-434. doi:10.1177/1077695814554294

Ergüçlü, S. (2011). Yazılarım. Kimgazet. Retrieved on 24 May 2014 from http:/ /www.erguclu.eu/

Gürcan, H. İ. (2002). İnternet haberciliğinde yazım tekniği yaklaşımları. Journal of the Communication Faculty, Istanbul University, 12(1), 27-54.

Heeter, C. (2005). Implications of New İnteractive Technologies for Conceptualizing Communication, Media use in the information age, Salvaggio, J. L. and Byrant, J. (Eds.). New Jersey: Lawrence Erlbaum.

Kırçıl, A. G., \& Karagüler, T. (2003). Dijital çağda iletişime yeni yaklaşım: online gazetecilik. Akademik Bilişim'03. 3-5 February 2003, Adana. 
Mitchelstein, E., \& Boczkowski, P. J. (2009). Between tradition and change: a review of recent research on online news production. Journalism, 10(5), 562-586. doi:10.1177/1464884909106533

Okoroafor, O. E. (2016). Media convergence: a paradigm shift in journalism education in Nigeria. Review of Journalism and Mass Communication, 4(1), 19-42. doi:10.15640/rjmc.v4n1a2

Öğüt, S. (2005). İletişim ortamlarında e-dönüşüm: yeni ortamlar. Retrieved on 12 December 2014 from http://www.sertacogut.com/blog/wp-content/uploads/2009/03/sertac_ogut_-iletisim_ortamlarinda_edonusum_yeni_ortamlar.pdf

Pavlik, J. V. (2001). Journalism and New Media. New York: Columbia University Press.

Peksevgen, B. S. (2016). Global dünyada değişen basın ve gazetecilik. Global Media Journal TR Edition, 6(12), 587600.

Press, J. (2015). A campus-wide j-school: news literacy as an avenue for journalism schools to connect with new students and a new generation. Toward 2020 New Directions in Journalism Education, S. Allen, S. Craft, C. Waddell \& M. L. Young (eds.), Toronto: Ryerson Journalism Research Centre.

Rafaeli, S. (1988) Interactivity: from new media to communication. Sage Annual Review of Communication Research: Advancing Communication Science, 16, 110-134.

Steensen, S. (2009). The shaping of an online feature journalist. Journalism, 10(5), 702-718. doi:10.1177/1464884909106540

Steur, J. (1992). Defining virtual reality: dimensions determining telepresence. Journal of Communication, 4(24), 7393.

Yıldırım, B. (2010). Gazeteciliğin dönüşümü: yöndeşen ortam ve yöndeşik gazetecilik. Selçuk İletişim, 6(2), 230-253.

\section{http://www.ejmste.com}

